\title{
CHARTING GEOGRAPHIC MENTAL MAPS IN FOREIGN POLICY ANALYSIS: A LITERATURE REVIEW
}

\author{
Luis da Vinha
}

International Relations Department, University of Coimbra, Portugal

\begin{abstract}
In recent years geographic mental maps have made a comeback into the spotlight of scholarly inquiry in the area of Foreign Policy Analysis (FPA). While never disappearing completely from scholarly examination, geographic mental maps were side-lined in most geographic and international relations (IR) research agendas. While geographers had long acknowledged the importance of mental maps in the study of international politics, few studies centred on the influence of geographic cognition on foreign policy. Only with the cognitive revolution in IR did geographic mental maps find space to develop conceptually and empirically with regards to international politics. Beginning with Henrikson's initial conceptualisation over three decades ago the mental map research agenda has adopted several different theoretical and methodological approaches which will be analysed in the current article.
\end{abstract}

Key words: Cognition, Foreign policy analysis, Geographic mental maps.

Article Info: Manuscript Received: February 24, 2012; Accepted: March 25, 2012; Online: May $29,2012$.

\section{Introduction}

In recent years geographic mental maps have made a comeback into the spotlight of scholarly inquiry in the area of Foreign Policy Analysis (FPA). The recent publication of several books entirely dedicated to the mental maps of an assortment of 2oth-century policymakers (Akçali, 2009; Casey and Wright 2008; 2011; Thomas, forthcoming), along with the organisation of several dedicated conferences and panels, e.g., the international conference "Mental Maps of Early Cold War", held at Oxford in September 2009, and the Third Global International Studies Conference, held in Porto in August 2011, have contributed to this trend.

While never disappearing completely from scholarly examination, geographic mental maps were sidelined in most geographic and international relations research agendas. Newer, fresher and more provocative avenues of investigation were pursued. Many of the themes associated with mental maps were incorporated into other approaches, namely those of critical and post-structural geographies.

\footnotetext{
* Correspondence address:

Address: Urb. Nova Conimbriga II, Lote B1 - R/C Dto 3150-230

Condeixa-a-Nova, Portugal.

Telephone: +351.967128805
}

There are several reasons for this phenomenon. The most important is certainly conceptual. As an analytical instrument for FPA, geographic mental maps continue to be an imprecise and underdeveloped concept (Criekemans, 2009; da Vinha, 2010; 2011a). Despite the continuous clamour of the importance of the role of geographic mental maps on policy-making throughout most of the 2othcentury, very little theoretical development and empirical evidence was presented to endorse such claims. With the exception of a few ground-breaking studies treating foreign policy issues, the study of geographic mental maps evolved along very different trajectories, leaving explanations of inter-state relations for others theorists to explain. It was only in the 1980 s that a systematic effort to "operationalise" the concept of mental maps in foreign policy analysis was undertaken, beginning with Alan Henrikson's essay The Geographical "Mental Maps" of American Foreign Policy Makers (Criekmans, 2009; da Vinha, 2011a; O'Loughlin and Grant, 1990).

The ensuing decades have tenuously furthered this line of investigation, albeit with numerous theoretical and methodological approaches. As a result, it has proven difficult to identify the geographic mental map research agenda's impact on international politics. 
This review looks to systematise the research that is dispersed throughout the many different fields but with a primary focus on the role of geographic cognition on foreign policy-making. Accordingly, the review begins by assessing how the concept of mental maps originated and has evolved over time, evaluating the epistemological and methodological diversity. However, it is important to point out that research in these various fields of knowledge has grown so extensively over the years thereby requiring that our focus be necessarily limited. Therefore, the proceeding review is illustrative, not comprehensive.

\section{Finding a Bearing in a Conceptual Quagmire}

The man-milieu relation has been central to the discipline of geography since its beginning. As Reginald Golledge (2002: 2) affirms "understanding Human-Environment Relations has been a constant theme throughout the history of geography". Nonetheless, the concept of environment has evolved considerably in the 2oth-century implying different theoretical and methodological approaches to deal with the concepts variance.

For much of that history "environment" largely referred to physical space (i.e., the tangible natural world). With increasing emphasis on the human side of this equation, "the environment" began to take on many new facets. Initially, the term was expanded to include the "built" environment (i.e., the tangible additions that humanity had made to the physical world). Then, in the latter part of the century, the term "environment" was expanded to include the behavioural environment (the environment of human interactions and movements), the socio-cultural environment (i.e., the hidden structures of customs, beliefs, and values that constrained human relations), the political environment (i.e., the human-defined boundaries, legal structures, an organizational structures within which human action takes place), and the cognitive environment (i.e., the internal representation of the world in our memories). (Golledge, 2002: 2)

Accordingly, research on geographic mental maps has to be placed in this historical context of scientific fluidity and diversity. The concept has assumed many nomenclatures, and its scope and methods have changed through the years. To properly understand the concept it is necessary to appreciate the intellectual underpinnings of its formation and evolution.

Accordingly, the first studies on mental maps and geographic perception and cognition can be traced back to the first half of the 2oth-century. One of these studies dates back to Charles Trowbridge's (1913) article On Fundamental Methods of Orientation and
"Imaginary Maps". Gary Moore and Reginald Golledge (1976: 16), consider this to be the "first systematic experiment on human knowledge of the large-scale environment". Nevertheless, the foundation of the modern study of mental maps is regularly attributed to Edward Tolman who coined the term "cognitive map" (Bell et al., 1996; Golledge and Stimson, 1997; Mark et al., 1999; Saarinen, 1987). By studying how rats learned to "map" the environment of experimental mazes, Tolman (1948) attempted to extrapolate his findings to human spatial orientation. After conducting various experiments with rats in order to demonstrate their capability of developing path learning skills from stimuli received from their surroundings, Tolman (idem) followed on by inquiring on "what are the conditions which favor narrow strip-maps and what are those which tend to favor broad comprehensive maps not only in rats but also in men?".

In the following years other studies regarding the cognition of geographic space were published but did not incite any particular scientific excitement (see Downs and Meyer, 1978; Mark et al., 1999; Moore and Golledge, 1976). However, it was with Kevin Lynch's publication of The Image and the City in 1960 that there was a "widespread interest in understanding the formation and use of humans' cognitive maps" (Bell et al., 1996: 81; see also Kitchin and Freundschuh, 2002; Saarinen, 1987).

As an urban planner Lynch sought to understand how people's perception of their environment could assist planners in bettering urban planning and design. Through the use of sketch maps, Lynch looked to uncover city-dweller's images of their cities - i.e., "the environmental image, the generalized mental picture of the exterior physical world that is held by an individual" (Lynch, 1960: 4). For Lynch the environmental image resulted from and interaction between the observer and his environment in which the latter suggests distinctions and relations, whereas the former "selects, organizes, and endows with meaning what he sees" (idem: 6).

In fact, the interest in environmental cognition ${ }^{3}$ had its defining moment in the 1960s (Downs and

\footnotetext{
${ }^{1}$ According to Downs and Meyer (1978) it is difficult identify precisely the "firsts" in terms of scientific research. Although recognizing that Trowbridge "was awarded the honor of being the first to study geographical orientation and imaginary maps", the authors (idem: 62) also acknowledge French psychologist Binet's contribution to the theme of geographical orientation in the late Nineteenth Century.

${ }^{2}$ While each individual has his own image, Lynch argued that city planners were essentially interested in group images or "public images" (1960: 7).

${ }^{3}$ As referred to previously, the terminology regarding the cognition of geographical space is extremely varied. However in the period following the 196os, the terms "environmental cognition", "environmental knowing" and "environmental perception" were widely used in the thematic literature to describe "the study of the
} 
Meyer, 1978; Moore and Golledge, 1976). The newly acquired interest in environmental cognition stretched across a wide array of disciplines, with fairly independent research agendas. Moore and Golledge (1976) identify five different lines of scientific inquiry during this period: urban planning, geography, anthropology, sociology, and psychology.

In urban planning, as stated beforehand, Lynch "was perhaps the single most important influence on environmental cognition" (Moore and Golledge, 1976: 17). His study on the environmental images of Boston, Jersey City, and Los Angles inspired a plethora of studies throughout the field of urban planning and is still today a reference for many urban designers throughout the world (LeGates and Stout, 1997). For its part, the anthropological dimension of environmental cognition focused on the comparison of cognitive systems on a cross-cultural level. Exemplary of this strand of cognitive anthropology is the study of "ethnosemantics" which focused on the relation between linguistic constructs and systems of meanings for organizing the world (Moore and Golledge, 1976). Sociologists approached environmental cognition from the perspective of "what people think and have thought about their cities" (idem: 20). The main work guiding sociological investigations into environmental cognition during this period was Anselm Strauss's Images of the American City published in 1961. His research, followed by other sociologists, centred on understanding the "total, holistic fabric of the structure, function, and meaning of urban and nonurban environments" (idem: ibidem).

According to Moore and Golledge (idem), psychology was the discipline that least contributed to individuals knowledge of large-scale environments. Albeit psychology's considerable contribution to spatial cognition and perception in general (see Bell et al., 1996; Downs and Stea, 2005a; Kitchin and Freundschuh, 2002), it has been, contrary to other disciplines, "more concerned with the construction of overall, general, explanatory theories than any of these other fields" (Moore and Golledge, 1976: 20).

Whilst some psychological studies focusing on large-scale environments were conducted during this period (see Moore and Golledge, 1976), it was in the field of geography that "work on environmental cognition has been most extensive" (idem: 17). The 1960 sitnessed a watershed in cognitive studies in

subjective information, images, impressions, and beliefs that people have of the environment, the way in which these conceptions arise from experience, and the ways in which they affect behavior with respect to the environment" (Moore and Golledge, 1976: 3). More precisely, environmental cognition refers to "the awareness, images, information, impressions, and beliefs that individuals have about the elemental, structural, functional, and symbolic aspects of real and imagined physical, social, cultural, economic, and political environments" (idem: 5). geography. According to Roger Downs and James Meyer (1978: 62) the works published in the 1940s and 1950 s by geographers Gilbert White, John Wright, William Kirk, and James Watson "served as the essential basis for the work that dominated the 196os". From outside the field of geography, Kenneth Boulding and Herbert Simon contributed considerably with their studies on images and the subjective nature of human behaviour to the enlargement of the behavioural approach to environmental issues (idem).

These works, along with the growing dissatisfaction of geographers with the epistemological and ontological basis of logical positivism prevalent in geography at the time (Unwin, 1995; Wolpert, 1964), reinforced the growing attention given to behavioural theories ${ }^{4}$. Regardless of the intellectual storm swirling around the subject, there continued to be evidenced a lack of conceptual and theoretical consistency that stymied geographers' best intentions to develop a homogeneous body of research ${ }^{5}$.

Where to begin was perhaps the most disturbing problem that we faced. Even the most cursory reading of the literature within geography revealed that we could not survive for very long by taking in our own laundry. We were forced into the literature of other disciplines. Who would not admit to fruitless days spent lurking in the BF section of the Library of Congress classification, patiently reading through psychology texts and journals in search of anything with perception in the title. And who would not confess to the frustration and disappointment as studies of neural processes in the octopus and binocular parallax and Fechner's Law revealed a terrible mistake. What "we" thought we meant by perception was not what "they" were talking about. (...) References to environment were equally disturbing; the environment for psychologists was a bizarre parody of what we were interested in. (Downs and Meyer, 1978: 64)

The difficulties referred to above did not, however, entirely obliterate some logical consistency in approaching the cognition of geographic space. Specifically, in accordance with Downs and Meyer (idem; see also Golledge and Stimson, 1997) two basic streams of research evolved with distinct philosophical perspectives and methodologies - i.e., "empirical" and "humanistic" approaches ${ }^{6}$. The

\footnotetext{
${ }^{4}$ For a more detailed description of the various factors leading to the emergence and development of behavioral geography see Golledge and Timmermans (1990: 57).

${ }^{5}$ Downs and Meyer (1978) refer to perceptual geography in their text, but their conceptualisation can today be placed in what has become generally designated as behavioural geography.

${ }^{6}$ Downs and Meyer (1978) partition these two distinct approaches further into a four-fold division. Accordingly, the humanist perspective could be divided into the "landscape school" (with its emphasis on affective relation between individuals and place) and
} 
empirical perspective favoured a more formal scientific method, "emphasizing empirical observation, validation through public consensus and verification, and the separation of the subjective value from the objective fact" (Downs and Meyer, 1978: 61). The humanistic approach, for its part, was interested in studying issues such as the individual's values, meanings, purposes, and goals. Ultimately, the humanist sought to reveal the lived-world or Lebenswelt as the true field of human knowledge (idem).

Nevertheless, the various scientific disciplines quickly began to converge, resulting in an increasingly multidisciplinary approach. As a result, the 1960 s and 1970 s witnessed a proliferation of studies covering a vast array of cross-disciplinary themes associated with geographic cognition. Along with the establishment of the Environment Design \& Research Association (EDRA) and the foundation of the journal Environment and Behavior in the late 196os, the multidisciplinary approach supplied a number of important publications (Kitchin and Freundschuh, 2002) ${ }^{7}$.

Of the assortment of works published in this period, some are worth special mention due to their influence on the future of the geographic mental map research agenda, namely those dealing with largescale environmental cognition. Of particular relevance is Image and Environment, edited by Roger Downs and David Stea in 1973, which consisted of one of the first introductory publications outlining the scope and various approaches involved in cognitive map research (Saarinen, 1987). Downs and Stea (2005a: 1) recognized the lack of "theoretical effort per se ... directed specifically to cognitive spatial representations". Their primary purpose was to clarify concepts and put forward an initial theoretical and methodological base to be applied in future research on cognitive maps.

Focusing heavily on psychology, the authors made pertinent observations as to the lack of a priori hypotheses, deficiency in measuring procedures, and terminological confusion (especially regarding perception and $\left.\operatorname{cognition}^{8}\right)$. Accordingly, the authors

"historical geography" (tracing the historical origins of geographical perceptions), whereas the empirical perspective was composed of by the "hazard perception" branch and the "cognitive mapping" branch (concerned with process from an empirical standpoint).

${ }^{7}$ For a comprehensive description of the various works dealing with the themes associated with the cognition of geographical space during this period see Golledge and Timmermans (1990) and also Moore (1979).

${ }^{8}$ The various studies dealing with mental maps has tended to use the terms "perception" and "cognition" in many different ways, usually confusing the two. In the present paper the term perception refers to "the process that occurs because of the presence of an object" (Downs and Stea, 2005b: 14), while cognition for its part "need not be linked with immediate behaviour and attempted to define the concept of "cognitive map" along with their relation to spatial behaviour. Equally significant was the clarification between the concepts of cognition and perception, which were being employed in a confusing manner by researchers in all fields. In addition, the fundamental questions of the nature and functions of cognitive maps were explored in order to find the answers to the questions of "what people need to know?", "what do people know?", and "how do people get their knowledge?" (idem: 16).

Another milestone work was Peter Gould and Rodney White's Mental Maps (1974). Gould and White were fundamentally interested in identifying, by using space preference maps, the way in which distances between an individual and a specific place affects the image building process (idem). The underlying assumption held by the authors was essential to understanding spatial decision-making and behaviour:

Human behavior is affected only by the portion of the environment that is actually perceived. We cannot absorb and retain the virtually infinite amount of information that impinges upon us daily. Rather, we devise perceptual filters that screen out most information in a highly selective fashion. (...) Our views of the world, and about people and places in it, are formed from a highly filtered set of impressions, and our images are strongly affected by the information we receive through our filters. This is why filter control is so crucial, both on a personal, individual basis and on a larger governmental scale. (Gould and White, 1974: 48)

Many additional works analysing large-scale geographic cognition were published during this period and had a profound influence on geographic thinking underling the fact that the concept of a mental map or cognitive map was naturally inspiring and logical to geographers:

Since behavior in space was seen to be the outcome of decision-making processes that rely on combining stored information with ongoing experience, the significance of the cognitive map as the mechanism for storing, recalling, and using such information was an appealing one and began to spread widely. (Golledge and Stimson, 1997: 225)

therefore need not be directly related to anything occurring in the proximate environment" (idem: ibidem). Accordingly, where perception is stimulus dependent, cognition concerns "more specific concepts and surrogates of sensation, perception, imagery, retention and recall, reasoning and problem solving, and the making of judgements and evaluations (i.e., decisions and choice)" (Golledge and Stimson, 1997: 191).

${ }^{9}$ Downs and Stea (2005b: 9) defined cognitive mapping as "a process composed of a series of psychological transformations by which an individual acquires, codes, stores, recalls, and decodes information about the relative locations and attributes of phenomena in his everyday spatial environment." 
In spite of the plethora of texts and the active research agenda, behavioural geography, particularly its study of cognitive and mental maps, diminished after the late 1970s (Golledge and Timmermans, 1990; Kitchin and Freundschuh, 2002). At the same time as alternative schools of thought were attracting geographers' attention ${ }^{10}$, behavioural theory came under fierce disparagement from inside the discipline of geography. In addition to questioning the relevant contribution made to geographic knowledge ${ }^{11}$, critics also charged behavioural geography for its mechanistic and dehumanising approach and its failure in recognizing the broader social and cultural framework in which decision-making occurred (Kitchin and Blades, 2002; Kitchin and Freundschuh, 2002; Unwin, 1995).

The diminishing attention paid to behavioural theories and especially mental maps throughout the last couple of decades does not imply that all work on geographic cognition was refrained. On the contrary, various researchers pursued the cognitive agenda in the field of geography (see Downs and Stea, 2005a; Golledge, 2003; Golledge and Stimson, 1997; Kitchin and Blades, 2002; Kitchin and Freundschuh, 2002; Lloyd, 1982; 1989; Mark et al., 1999). Many theories and methods were developed and consolidated over the years, although there still does not exist a widespread consensus for dealing with the cognition of geographic space (Kitchin and Freundschuh, 2002). Moreover, humanist and qualitative perspectives have been integrated in order to improve the research agenda. As a result, behavioural geography at present "can be characterized by a concern both for scientific rigor or experimental realism and for phenomenological and anthropomorphic understanding of human-environment systems and relationships" (Golledge and Stimson, 1997: 29).

Through the use of these varied approaches the research agenda has expanded to include a wide assortment of issues such as 1) studies of cognitive mapping and spatial behaviour; 2) attitudes, utility, choice, preference, search, and learning; 3 ) consumer behaviour; 4) location decision-making; 5) wayfinding, mode choice, and travel behaviour; 6) mobility and migration behaviour; 7) societal, materialist, or feminist interpretations of urban structure; 8) social reality of housing markets; 9) environmental ethics; 10) planning and policymaking; 11) social problems of the homeless and other disadvantaged groups (idem).

\footnotetext{
${ }^{10}$ The most attractive theories in the 1970 s were the humanist theories with their phenomenological tradition, and the Marxist inspired radical theories (Claval, 2006; Unwin, 1995).

${ }^{11}$ For an extensive account of the debate between supporters and critics of the behavioral approach see Golledge and Timmermans (1990).
}

Notwithstanding evolving interpretations regarding the significance and development of research on geographic cognition, most studies have tended to focus on scales that range from the micro space (space of the body) to the neighbourhood or city scale. Cognitive research of large-scale spaces, such as the global-scale, is infrequent. One of the principal reasons for the lack of research of largescale environments is due to their transperceptual dimension. This implies that large-scale spaces "are generally too large to be perceived all at once" and can only be experienced "by the integration of perceptual experiences over space and time through memory and reasoning, or through the use of smallscale models such as maps (Mark et al., 1999: 748; see also Battersby and Montello, 2009).

Some studies have devoted themselves to these larger geographic scales ${ }^{12}$. Most of these studies however tend to concentrate on very specific theoretical and methodological issues, applying intensive empirically-oriented approaches. More precisely, the majority of the contemporary research on large-scale geographic cognition is interested in the acquisition, representation and schematization, and communication of the information (Mark et al., 1999). This information is of particular concern to researchers working on problems of navigation and orientation (Tversky, 2003). Studies on the distortions of acquired geographic information have been equally significant in recent years (Battersby and Montello, 2009).

For the most part, however, studies of large-scale environments have avoided analysing the implications of mental maps in decision-making, especially in relation to international politics. While geographers such as Saarinen (2005: 148) had long pointed to the importance of mental maps in the study of international politics by stating that "it seems important in a world continually upset by international conflicts to try to gain an understanding of variation in world views", this perspective went largely ignored for many years. Only with the cognitive revolution in IR did geographic mental maps find space to develop conceptually and empirically with regards to international politics.

\section{Geographic Mental Maps and the Cognitive Dimension in FPA}

The "rational actor" is one of the most wellestablished concepts in International Relations

\footnotetext{
${ }^{12}$ For a detailed account of the recent scientific research carried out on large-scale geographic space (global-scale) see Allen (1985), Battersby and Montello (2009), Golledge and Stimson (1997), Mark et al. (1999), and Montello (1998).
} 
(Allison and Zelikow, 1999; Holsti, 2006; Hudson and Vore, 1995; Rosati, 2005). According to Rosati:

Traditionally, foreign policy has been explained from a rational actor perspective common to the realist and power politics tradition. The assumption has been that governments, and their political leaders, think and act in a rational manner in their quest for power and order. Such rationality assumes that individuals perceive the world accurately and arrive at decisions through an open intellectual process: goals are ordered, a search is made for relevant information, a wide range of alternatives is considered, and the option that maximizes the benefits while minimizing the cost is selected. (Rosati, 2005: 50)

Nevertheless, the end of the Cold War left rational explanations wanting. According to Valerie Hudson and Christopher Vore (1995), mainstream theories of IR were unable to predict the demise of the bi-polar confrontation and to explain the new complex international environment. In their critique of the time-honoured theories that dominated IR, especially rationally-centred explanations, Hudson and Vore (idem) insist that there is a lack of comprehension of human political choice. Specifically, the established theories failed to recognize that "with every system transformation ... human will and imagination are major influences in shaping world affairs" (idem: 210).

The alternative to the "rational" perspective came from the designated "cognitive revolution" (Hudson and Vore, 1995; Rosati, 2005). This approach has guided a vast array of research in IR that departed from the traditional theories, particularly by viewing human rationality as bounded. Accordingly, the cognitive approach is predisposed to examine the individuals involved in decision-making process and the complex environment in which they work:

People sacrifice rather than optimize. They neither posses nor seek perfect information. They seem incapable of considering more than two or three alternatives at a given time. They process information in different ways under stress than under routine conditions. Furthermore, because any situation can be interpreted in a myriad of ways depending on the historical precedents used, the personalities and experiences of the individuals interpreting the situation and their social and cultural predispositions are important in making decisions. Hidden agendas, such as the need to maintain group consensus or the desire to protect or extend "turf" can undermine a rational cataloging of expected costs and benefits. Emotional and ideological motivations can similarly undercut a rational cost/benefit analysis. Moreover, the greater the number of people involved in a decision, the greater the complexity of the decision calculus. (Hudson and Vore, 1995: 211)
The last two and a half decades have seen a substantial growth in cognitive research in IR (Tetlock and McGuire, Jr., 1999). Nevertheless, while occupying a peripheral position in IR for many years, cognitive factors have long been recognized as vital to political decision-making (Holsti, 1976; 2006). The initial works clearly applying psychological concepts in political studies commenced in the 1930 s and continued for the next several decades (Rosati, 2005). However, most of these early works were conducted by psychologists and had little impact on IR theorists. It was only in the 1950 os that the "contribution of psychological approaches to the study of international relations grew in importance due to the interaction of the 'peace research' movement and the "behavioral' revolution in the social sciences" (idem: 51). The IR theorists who adopted a decision-making approach to the study of foreign policy especially favored the psychological approach.

One of the milestone studies was Foreign Policy Decision-Making, published by Richard Snyder et al., in 1962. Richard Snyder et al., study's most important contribution to IR theory was identifying the human decision-maker as the key determinant of state behaviour. Though recognizing that the nation-state would continue to be the significant unit of political action for the foreseeable future, Snyder et al. (2002) centred the analysis on the decision-maker and his understanding of the situation:

State action is the action taken by those acting in the name of the state. Hence, the state is its decisionmakers. State $\mathrm{X}$ as actor is translated into its decisionmakers as actors. It is also one of our basic choices to take as our prime analytical objective the re-creation of the "world" of the decision-makers as they view it. The manner in which they define situations becomes another way of saying how the state oriented to action and why. (Snyder et al., 2002: 59)

Equally important to the development of the cognitive approach to foreign policy was the research carried on by Harold and Margaret Sprout (1957; $1960 ; 1965)$. By focusing on the ecological perspective in foreign policy, the Sprouts $(1957 ; 1965)$ looked to demonstrate how policies are related to the environment in which the political decisions were taken and carried out. In order to express the distinct cognitive dimensions in foreign policy, the Sprouts differentiated the psycho-milieu (the environment as is perceived and reacted to bay a particular individual) from the operational milieu (the environment in which the individual's decision are executed). This distinction is fundamental to comprehend the complexity involved in foreign policy: 
With respect to policy-making and the content of policy decisions, our position is that what matters is how the policy-maker imagines the milieu to be, not how it actually is. With respect to the operational results of decisions, what matters is how things are, not how the policy maker imagines them to be. (Sprout and Sprout, 1957: 327-328)

Along with a few other studies conducted during this period, this first generation of research in international politics contributed to the systematic study of the beliefs and images of foreign policymakers throughout the next generation of IR scholars (Rosati, 2005). Yet, it was Robert Jervis's (1976) Perception and Misperception in International Politics that systematically incorporated for the first time psychological knowledge and international politics. For Jervis (idem: 4) "most psychological theories, and especially those that have been applied to international relations, do not account for the ways that highly intelligent people think about problems that are crucial to them". As a result, in order to benefit from psychologies theoretical contributions, Jervis chose a broad and eclectic approach that employed diverse theories and experimental findings in psychology - e.g., attitude change, social psychology, cognitive psychology, and visual perception.

Jervis's work, along with John Steinburner's The Cybernetic Theory of Decision (1974) reflected the "cognitive revolution" that swept psychology in the early 1970s. The major effect of this revolution was in changing the way the individual's interaction with his environment was conceived. More precisely, the human being began to be understood as dynamic, rather than a passive agent - i.e., who selectively responded to and actively shaped his environment instead of passively responding to its stimuli (Rosati, 1995).

The ensuing years witnessed the development of a considerable amount of research that applied a wide variety of concepts, theoretical foundations, subjects, and "data-making" operations, making the cognitive approach to IR an eclectic research field (Holsti, 2006). Nevertheless, by this time the different studies embodied most of the core assumptions that permeated the cognitive perspective in foreign policy analysis ${ }^{13}$.

Tetlock and McGuire Jr. (1999) have identified two key assumptions at the core of the cognitive research agenda. The first states that the international environment is highly demanding in terms of information processing due to the complexity which results from incomplete and variable information. Also, decision-makers must many times operate

\footnotetext{
${ }^{13}$ For a more detailed list of works see Holsti (2006); Hudson (2002); Rosati (2005); Tetlock and McGuire, Jr. (1999).
}

under tremendous stress and pressure, limiting their capacity to choose utility-maximizing solutions. The second assumption asserts that due to decisionmaker's limited information processing capabilities, they tend to employ simplifying schemes to deal with the immense complexity of the international environment. Accordingly, decision-makers construct simplified images of their political world in order to cope and come to a decision.

From these key assumptions Tetlock and McGuire Jr. (1999: 506) proceed to identify the cognitive research program's central research objective as the understanding of the "cognitive strategies that policymakers rely upon to construct and maintain their simplified images of the environment". They further differentiate between two types of cognitive strategies.

The first strategy corresponds to representational research, which relies on cognitive or knowledge structures that provide the framework for incorporating new informational inputs and choosing between the diverse policy options. These studies look to explain what policymakers think. This requires understanding their assumptions about themselves, other states, inter-state relationships, the goals and/or values underlying foreign policy, and the types of policies most helpful to achieving those goals or values. Some of the concepts most readily applied to describe these cognitive structures are "scripts", "operational codes", "cognitive maps", "images", "stereotypes", "frames", "prototypes", and "schemas".

The second strategy acknowledged represents process research, with its principal focus on identifying the abstract laws of cognitive functioning that clarify how policymakers think about issues. The majority of this research looks to comprehend the rules and/or procedures that underlie the policymaking decision process. Some of the most significant lines of research in the process strategy are on the fundamental attribution error, extracting lesson from history, avoidance of value trade-offs, the policy-freezing effects of commitment, and crisis decision-making. As a result, in all these cases "the cognitive miser image of the decision maker serves as leitmotif: policymakers often seem unwilling or unable to perform the demanding informationprocessing tasks required by normative models of judgment and choice" (Tetlock and McGuire Jr., 1999: 511).

Accordingly, it is in the context of the cognitive research agenda that geographic mental maps must be framed in FPA. The cognitive dimension of FPA opened up space for analysing geographic representations, namely foreign policy decisionmakers cognition of geographic space. 


\section{Geographic Mental Maps and the Study of Foreign Policy}

Despite the preliminary contribution of Harold and Margaret Sprout $(1957 ; 1960 ; 1965)$ and of Snyder et al. (2002) in the 1950s and 1960s, it was Henrikson's The Geographical "Mental Maps" of American Foreign Policy Makers, published in 1980, that first applied the "geographical mental map"14 as a conceptual instrument for foreign policy analysis ${ }^{15}$. Acknowledging that traditional political science has long been ill-equipped to deal with the geographic perceptions underlying foreign policy decisions, Henrikson argued that the mental map permits a better understanding of how individuals come to understand the spatial relationships involved in foreign policy-making:

More important than knowing the names, locations, and sizes of countries is an awareness of the spatial processes we are caught up in. The matter of acquiring such a "geographic sense" is complex, even in technical terms. (...) Geography means much more than territory; even the meaning of the latter continually changes. (...) The mental-map approach to the study of international affairs is well suited to this increasingly fluid context. One of its major strengths is that it enables us immediately to recognize the vague and shifting character of the environments within which statesmen act. (Henrikson, 1980a: 504-505)

With the intention of providing a functional framework for analytical purposes, Henrikson expanded the conceptual knowledge of geographic mental maps. Accordingly, he began by identifying the formational factors subjacent to mental maps i.e., the maps cognitive base and a person's worldview (or Weltanschauung) - and proceeded to describe the appropriate methods for analysing an individual's mental maps - the geographical mind and the geographical field. According to the author, examining the geographic mind, or "ideology" of the individual, can best be accomplished by making use of the methods of intellectual history and content analysis:

The aim is, through a careful analysis of the language (visual as well as verbal) used in public speeches, diplomatic notes, treaty texts, cartographic annexes,

\footnotetext{
${ }^{14}$ In a conceptualization close to that of Downs and Stea (2005b), Henrikson (1980a: 498) defines mental map as "an ordered but continually adapting structure of the mind - alternatively conceivable as a process - by reference to which a person acquires, codes, stores, recalls, reorganizes, and applies, in thought or action, information about his or her large-scale geographical environment, in part or in its entirety".

${ }^{15}$ Henrikson $(1975 ; 1980 b)$ had previously analysed how geographic perceptions had influenced US foreign policy, especially through the analysis of different cartographical constructions.
}

and the like, to determine the key geographical concepts and related images that...officials more or less consciously entertain in making, conducting, and justifying foreign policy. (Henrikson, 1980a: 509)

Nevertheless, Henrikson insisted that it does not suffice to examine the ideological content of a decision-maker; "one must also have a reliable, nearly intuitive sense of the geographical milieu through which one moves" (idem: ibidem). This implies plotting the space in which an individual moves in carrying out his various occupational and social roles - i.e., the geographic field. By describing the actual life patterns of individuals (e.g., official travels), specifically by plotting the activity on cartographic charts, it is possible to record the geographic behaviour of decision-makers and policy-makers. In brief, the two concepts can be hypothesized as typifying foreign policy planning (geographic mind) and the conduct of diplomacy (geographic field) (idem).

At the core of foreign policy-maker's geographic mind are what Henrikson (idem: 512) designated as "image-plans", combining the visual and logical (or abstract) elements that inform their "grand strategies" and "grand designs". For its part, the geographic field comprehends an activity-generated space or "behavior-space", which results from personal experience (idem: 517). To fully understand how geographic mental maps influence foreign policy-maker's behaviour, Henrikson argued that these two factors must be considered together, for large-scale image-plans may help keeping the environmental complexity in a comprehensible perspective, but "they must be accompanied by keen familiarity with smaller behaviour-spaces at ground level" (idem: 525).

Henrikson's work encouraged additional research on geographic mental maps applied to international politics. However, theoretical development and empirical cases lagged. A decade after Henrikson published his essay on mental maps, John O'Loughlin and Richard Grant (1990: 507) conceded that "to date researchers have not attempted to relate cognitive maps and political images". For their part, O'Loughlin and Grant (idem) analysed the post-war State of the Union addresses to uncover the mental maps of American presidents. According to the authors, each speech constituted an illustration of the world-views the presidents wanted to describe and interpret for the American public. Applying an "environmental model", O' Loughlin and Grant used a content analysis method to identify the most significant regions for American foreign policy. More specifically, the study held "that the amount of attention, as measured by the number of speeches, paragraphs, words, etc., is an accurate reflection of 
the concern and importance that leaders in the Western world attach to places and events" (idem: 509).

Henrikson (2002) took up his previous argument once more in Distance and Foreign Policy: A Political Geography Approach. He insisted yet again that "Geographical ideas, images, and associated reasoning processes, which may not be completely conscious or fully articulated in speech, do exist in the minds of foreign policy makers" (idem; 440-441). In particular, cognitively constructed distance is important in foreign policy-making. Henrikson identifies three types of distances that shape policymaker's comprehension of foreign places and the events taking place there - i.e., gravitational distance, topological distance, and attributional distance. Distancing himself from his critics, Henrikson defended that these distance schemes correspond top how foreign policy-makers actually think when they strategize and plan:

This is "practical geopolitics", characteristic of the reasoning that occurs in foreign policy bureaucracies and political institutions, as distinct from what Gearóid Ó Tuathail and Simon Dalby, in their taxonomy term "popular geopolitics", characteristic of the mass media, and "formal geopolitics", characteristic of the academe. (Henrikson, 2002: 439-440)

While reinforcing the importance of the influence of geographic cognitions on foreign policy, Henrikson's work has had few followers. While some studies dedicated to geographic cognition associated to international politics have been published in recent years (see Bilgin, 2004; Glassman, 2005; Latham, 2001; Le Rider, 2008; Scheffler, 2003; Walker, 200o), most have tended to focus on regional perspectives. Other works, while more global in scope (see Bialasiewicz et al., 2007; Lewis and Wigen, 1997; Sloan, 1988), have not focused directly on the way that geographic mental maps inform the decisionmaking and policy-making processes ${ }^{16}$, rather concentrating on the way geographic constructions have justified foreign policy decisions. In a general sense, most of these works can be understood within a critical geopolitics approach.

In fact, some of the main epistemological propositions stressed by the earlier work on mental maps have come under censure from critical

\footnotetext{
${ }^{16}$ In fact, many of these studies do not apply the "mental map" as their analytical concept. Many different terms are used to characterize the cognitively constructed geographies informing foreign policy - e.g., "cognitive geopolitics" (Criekemans, 2009), "geopolitical codes" (Dijkink, 1998), "geopolitical images" (O'Loughlin and Grant, 1990), "geopolitical imaginary" (Latham, 2001), "geopolitical imagination" (Agnew, 2003) "imaginative geographies" (Bialasiewicz et al., 2007), and "metageographies" (Lewis and Wigen, 1997).
}

geopolitics. Klaus Dodds (1994) has questioned the geographic practice of representing the political world, specifically calling on the contributions of critical and post-structuralist theories to point out that “'geography' (or 'international relations') as a technology or an academic discipline is not simply about 'geographing' or 'earth-writing', i.e., a practice whereby geographers simply record the already legible surfaces of the earth" (idem: 187). According to Dodds, discourses of geographic representations are frequently central to the legitimisation of foreign policy which fix the boundaries between "Us" and the "Others".

Critical geopolitics is thus centred on exploring how foreign policy professional represent political space according to their position in the world. This differs from previous research according to Dodds (idem: 197) who criticizes Henrikson's work on mental maps for having "little recognition that the observer might be implicated within these observations or that it might be reasonably problematic in assuming one could (re)present the activities of others". Consequently, scholars committed to critical geopolitics have developed much of the work on geographic representations in foreign policy. Relying on discourse analysis and similar methods, the central assertion of critical geopolitics is "that geography is a social and historical discourse which is always bound up with questions of politics and ideology" (Ó Tuathail and Agnew, 1998: 79). More specifically:

Fundamental to this process is the power of certain national security elites to represent the nature and defining dilemmas of international politics in particular ways. From a geographical perspective this can be described as their power to write international political space by constituting, defining and describing security, threats and perceived enemies in regularized ways. These representational practices of national security intellectual generate particular "scripts" in international politics concerning places, people and issues. Such scripts then become part of the means by which hegemony (in the Gramscian sense) is exercised in the international system. (Ó Tuathail, 1992: 438).

However, throughout the years, critical geopolitics has come to diversify its focus. Especially in its AngloAmerican version, critical geopolitics has broadened its research to encapsulate geopolitical practices, geopolitical traditions, geopolitics and popular culture, and structural geopolitics (Dodds, 2001). In fact, the original emancipatory temperament of critical theory has vanished from much of the selfdesignated critical geopolitics research. The multiplication of these studies has led Dalby (2010: 281) to suggest that "the term critical geopolitics is now in danger of proliferating to such an extent that 
the term simply becomes a synonym for contemporary political geography".

Accordingly, in recent years, two main avenues of research have been followed in the mental map research agenda in FPA. The first and prevailing approach is representational in nature, i.e., its major focus is on the content of foreign policy decisionmakers mental maps. For instance, returning to a familiar theme ${ }^{17}$, Henrikson (2008) has examined how Franklin D. Roosevelt's (FDR) mental map or "geographic-cartographic frame" conditioned US policy, namely by moulding popular conceptions of world geography. In his study, Alan Henrikson explains how FDR's mental maps justified US foreign policy by using a particular global view to transition "from geography to ideology":

For him, the map was an "idea". In his speeches he set out a geospatial framework - a worldwide one - for the higher, long-term, even planetary "goals" of the war, far beyond its military objectives. (...) Through FDR's rhetoric, his global thinking, on a geographical plane, reemerged as universal thinking on an ideological plane. His world-picture thus became his, and others', worldphilosophy. (Henrikson, 2008: 46).

In this sense, Henrikson assumes the subjective nature of geographic mental maps. By acknowledging the power-laden dimension of mental maps he also responds to some of the earlier criticism of his work. In a similar vein, Steven Casey and Jonathan Wright (2008; 2011) recently edited a collection of essays on various world leaders' post-war mental maps. Applying the concept of mental maps as tantamount to political worldviews, the authors explore the geographic conceptions that influenced the policymaking of numerous national leaders - e.g., Raymond Poincaré, Lloyd George, Mustafa Atatürk, Mao Zedong, Adolf Hitler, Benito Mussolini, Edvard Benes, Winston Churchill, Franklin Roosevelt, etc. While constituting the single most extensive collection of different foreign policy-maker's mental maps, the studies do not present any theoretical framework for applying the mental map approach. Besides equating mental maps to worldviews, no further attempt to conceptualise mental maps is put forward.

In an apparent response to these theoretical shortcomings, a second approach focusing on the geographic mental map's conceptual structure has been gaining ground recently. In an effort to contextualise mental maps in FPA, David Crieckmans and colleagues (Crieckmans, 2009; 2011; Crieckmans and Duran, 2011) have evoked the Sprout's “ecological

\footnotetext{
${ }^{17}$ Henrikson (1975) had previously studied how US geographical conceptions had been transformed by a change in the cartographic representations during the Second World War period (namely by adopting an "Air-Age Globalism" perspective).
}

triade" to identify the ontological and epistemological assumptions and traits of what he designates as "cognitive geopolitics". Crieckmans has also endeavoured to integrate classical, cognitive, and critical geopolitics in order for us to better appreciate the complex relationship between the "geo" and the "politics". Indeed, Crieckmans (2011: 8) argues that the "road towards a 'more comprehensive' geopolitical model or framework of analysis could therefore be one which entails several aspects of the interaction between 'territoriality' and 'politics".

Some research has followed an even more conceptually oriented approach. For example, da Vinha (2010; 2011a) has focused on analysing the concept of the geographic mental map and the way that individuals acquire geographic knowledge from their political environment. Borrowing from the earlier studies in behavioural geography, the author has looked to understand how foreign policydecision-makers acquire the geographic information required for the decision-making process. More recently, the research focus has turned to the effect of group dynamics on mental maps and how these, subsequently, affect decision-makers. By applying theoretical assumptions from social psychology, da Vinha has expanded on theories of social sharing and social cognition to try to appreciate how foreign policy decision-making groups construct a common understanding of the geographic factors involved in international politics:

Rather than focusing on the individual mental maps of those involved in the decision-making process we should look to the geographic representations created by the group. We should try to understand in each particular instance how the group - i.e., the decision unit - constructs the political world, namely how it creates places and spaces and the foreign policies it deems most appropriate for interacting with them. (da Vinha, 2011b: 58)

\section{Final Considerations}

In recent decades, a number of works relating geographic mental maps to foreign policy have appeared. However, despite the various efforts to clarify and explain the conceptual framework underlying the geographic mental map research agenda, there still persists a good deal of theoretical bewilderment. The concept of geographic mental map has diverged considerably in its definition and numerous methodological approaches have been undertaken to clarify it. However, no scholarly compromise has yet been established. Mental map is still used as a catch-all term with only very vague notions of its conceptual underpinnings. 
Consequently, several issues still need to be addressed. First and foremost, the development of a theory on how geographic mental maps actually influence decision-making and foreign policy-making is needed - i.e., the causal affects of geographic mental maps on foreign policy. If it has been difficult to demonstrate the causation of ideational factors in the political world (Yee, 1996), specifying the role of geographic ideas has revealed itself even more illusive. Enlarging the methodological scope for analyzing the mental map's influence of foreign policy is also imperative. While there has been a considerable attempt to try to widen the methods applied to metal maps in FPA, it will certainly be difficult to provide a single satisfactory approach for all scholars.

Even more vital to the mental maps research agenda is the lack of a comprehension of the affects of changes in mental maps on foreign policy. Despite the fact that some researchers have recognized that mental maps are dynamic and that the cognition of geographic space is in constant flux (Agnew, 1999; Gould and White, 1974; Moore and Golledge, 1976; Saarinen, 2005), few studies, if any, have focused on policy change. Albeit avowing that the "mental-map approach to the study of international affairs is well suited to this increasingly fluid context" (Henrikson, 1980a: 505) it has seldom been empirically applied in order to comprehend the shifting character of the environments within which foreign policy is made.

For the whole, a review of the scientific literature relating to geographic mental maps reveals itself complex and sometimes overbearing. The vast number of themes comprising the research agenda, paralleled by the immense diversification of theories and methods, seriously challenges a coherent approach to the study of geographic cognition and mental maps, particularly in FPA. It suffices to point out that Daniel Montello and Scott Freundschuh (1995: 170) have acknowledged approximately 200 combinations resulting from the "lists of terms that have been or could be used as labels for knowledge of spatial relations in the environment".

Ultimately, Downs and Meyer (1978) identified the cause for such diversity over a quarter century ago. They reminded researchers "there is no 'right' way to look at the world" (idem: 73). In actual fact, the different geographic knowledge generated by the various studies are "not in competition for the 'truth'; they are alternative approaches to understanding" (idem: 67). Instead of looking at the plethora of approaches as a shortcoming, we might begin acknowledging it as a constructive way of bringing several different fields of inquiry together to further our understanding of the place of geography in international politics, particularly in FPA.

\section{References}

Agnew, J 2003, Geopolitics- Re-visioning World Politics, Routledge, New York.

Akçali, E 2009, Chypre: Un enjeu géopolitique actuel, L'Harmattan, Paris.

Allen, G 1985, 'Strengthening Weak Links in the Study of the Development of Macrospatial Cognition' in R Cohen (ed) The Development of Spatial Cognition, Lawrence Erlbaum Associates, Publishers, Hillsdale, New Jersey, 301-321.

Battersby, S \& Montello, D 2009, 'Area Estimation of World Regions and the Projection of the Global-Scale Cognitive Map', Annals of the Association of American Geographers, 99 (2), 273-291.

Bell, P, Greene, T, Fisher, J \& Baum, A 1996, Environmental Psychology, Harcourt Brace College Publishers, Orlando, Florida.

Bialasiewicz, L, Campbell, D, Elden, S, Graham, S, Williams, A 2007, 'Performing Security: The Imaginative Geographies of Current US Strategy', Political Geography, 26, 405-422.

Bilgin, P 2004, 'Whose 'Middle East'? Geopolitical Inventions and Practices of Security', International Relations, 18 (1), 25-41.

Casey, S \& Wright, J (eds) 2008, Mental Maps in the Era of Two World Wars, Palgrave-Macmillan, New York.

Casey, S \& Wright, J (eds) 2011, Mental Maps in the Early Cold War Era, 1945-68, Palgrave-Macmillan, New York.

Claval, P 2006, História da Geografia, Edições 70, Lisboa.

Criekemans, D 2011, 'Réhabilitation et Rénovation en Matière de Pensée Géopolitique', L'Espace Politique. 12 (3), 2-13.

Criekemans, D 2009, 'Where 'geopolitics' and 'foreign policy analysis' once met: the work of Harold and Margaret Sprout and its continued relevance today', Paper presented at the annual meeting of the ISA's 5oth Annual Convention Exploring the Past, Anticipating the Future.

Criekemans, D \& Duran, M 2011, 'Mental Maps, Geopolitics and Foreign Policy Analysis: Basic Analytical Framework and Application to Sub-state Diplomacy in the Mediterranean', Paper presented at the WISC - Third Global International Studies Conference.

da Vinha, L 2011a, 'Assessing the Conceptual 'Goodness' of Geographic Mental Maps for Foreign Policy Analysis' Romanian Review on Political Geography. 13 (2), 133-148.

da Vinha, L 2011b, 'Georeferencing Foreign Policy: The Role of Geographic Mental Maps in Foreign Policy DecisionMaking', Paper presented at the WISC - Third Global International Studies Conference.

da Vinha, L 2010, 'Acquiring Geographic Knowledge in International Politics', Universitas: Relações Internacionais, 8 (2), 53-94.

Dalby, S 2010, 'Recontextualising Violence, Power and Nature: The Next Twenty Years of Critical Geopolitics?' Political Geography, 29 (5), 280-288.

Dijkink, G 1998, 'Geopolitical Codes and Popular Representations', GeoJournal. 46 (4), 293-299.

Dodds, KJ 1994, 'Geopolitics and Foreign Policy: Recent Developments in Anglo-American Political Geography and International Relations', Progress in Human Geography. 18 (2), 186-208. 
Dodds, KJ 2001, 'Political Geography III: Critical Geopolitics after Ten Years', Progress in Human Geography. 25 (3), 469-484.

Downs, R \& Meyer, J 1978, 'Geography and the Mind: An Exploration of Perceptual Geography', American Behavioral Scientist. 22 (1), 59-77.

Downs, R \& Stea, D (eds) 2005a, Image and Environment: Cognitive Mapping and Spatial Behavior, Transaction Publishers, New Brunswick, New Jersey.

Downs, R \& Stea, D 2005b, 'Cognitive Maps and Spatial Behavior: Process and Products' in R Downs \& D Stea (eds) Image and Environment: Cognitive Mapping and Spatial Behavior, Transaction Publishers, New Brunswick, New Jersey, 8-26.

Glassman, J 2005, 'On the Borders of Southeast Asia: Cold War geography and the construction of the other', Political Geography, 24, 784-807.

Golledge, $\mathrm{R}$ 2003, 'Reflections on Recent Cognitive Behavioral Research with an Emphasis on Research in the United States of America', Australian Geographical Studies, 41 (2), 117-130.

Golledge, R 2002, 'The Nature of Geographic Knowledge', Annals of the Association of American Geographers. 92 (1), 1-14.

Golledge, R \& Stimson, R 1997, Spatial Behavior: A Geographic Perspective, The Guilford Press, New York.

Golledge, R \& Timmermans, H 1990, 'Applications of Behavioural Research on Spatial Problems I: Cognition', Progress in Human Geography, 14 (1), 57-99.

Gould, P \& White, R 1974, Mental Maps, Penguin Books, Middlesex.

Henrikson, A 2008, 'FDR and the "World-Wide Arena" in D Woolner, W Kimball, \& D Reynolds (eds) FDR's World: War, Peace, and Legacies, Palgrave-Macmillan, New York, 35-61.

Henrikson, A 2002, 'Distance and Foreign Policy: A Political Geography Approach', International Political Science Review, 23 (4), 437-466.

Henrikson, A 1980a, 'The Geographical 'Mental Maps' of American Foreign Policy Makers', International Political Science Review, 1 (4), 495-530.

Henrikson, A 1980b, 'America's Changing Place in The World: From 'Periphery' to 'Centre'?' in J Gottman (ed.) Centre and Periphery: Spatial Variation in Politics, Sage Publications, Beverly Hills, California, 73-100.

Henrikson, A 1975, 'The Map as an 'Idea': The Role of Cartographic Imagery during the Second World War', The American Cartographer. 2 (1), 19-53.

Holsti, O 1976, 'Foreign Policy Formation Viewed Cognitively' in R Axelrod (ed.) Structure of Decision: The Cognitive Maps of Political Elites, Princeton University Press Princeton, New Jersey, 18-54.

Holsti, O 2006, 'Cognitive Process Approaches to DecisionMaking: Foreign Policy Actors Viewed Psychologically' in O Holsti (ed) Making American Foreign Policy, Routledge, New York, 33-51.

Hudson, V \& Vore, C 1995, 'Foreign Policy Analysis Yesterday, Today, and Tomorrow', Mershon International Studies Review, 39 (2), 209-238.

Kitchin, R \& Blades, M 2002, The Cognition of Geographic Space, I B Tauris \& Co Ltd, New York.

Kitchin, R \& Freundschuh, S (eds) 2002, Cognitive Mapping: Past, Present and Future, Routledge, London.
Latham, A 2001, 'China in the Contemporary American Geopolitical Imagination', Asian Affairs: An American Review, 28 (3), 138-145.

LeGates, R \& Stout, F (eds) 1997, The City Reader, Routledge, New York.

Le Rider, J 2008, 'Mitteleuropa, Zentraleuropa, Mittelosteuropa: A Mental Map of Central Europe', European Journal of Social Theory, 11 (2), 155-169.

Lewis, M \& Wigen, K 1997, The Myth of Continents: A Critique of Metageography, University of California Press, London.

Lloyd, R 1982, 'A Look at Images', Annals of the Association of American Geographers, 72 (4), 532-548.

Lloyd, R 1989, 'Cognitive Maps: Encoding and Decoding Information', Annals of the Association of American Geographers, 79 (1), 101-124.

Lynch, K 1960, The Image of the City, Massachusetts: The MIT Press, Cambridge.

Mark, D, Freksa, C, Hirtle, S, Lloyd, R \& Tversky, B 1999, 'Cognitive Models of Geographical Space', International Journal of Geographical Information Science, 13 (8), 747774 .

Montello, D 1998, 'A New Framework for Understanding the Acquisition of Spatial Knowledge in Large-Scale Environments' in M Egenhofer \& R Golledge (eds) Spatial and Temporal Reasoning in Geographic Information Systems, Oxford University Press, New York, 143-154.

Montello, D \& Freundschuh, S 1995, 'Sources of Spatial Knowledge and their Implications for GIS: An Introduction', Geographical Systems, 2, 169-176.

Moore, G 1979, 'Knowing About Environmental Knowing', Environment and Behavior, 11 (1), 33-70.

Moore, G \& Golledge, R 1976, 'Environmental Knowing: Theories and Concepts' in G Moore \& R Golledge (eds) Environmental Knowing: Theories, Research and Methods, Dowden, Hutchinson \& Ross, Stroudsburg, Pennsylvania, 3-24.

O'Loughlin, J \& Grant, R 1990, 'The Political Geography of Presidential Speeches, 1946-87', Annals of the Association of American Geographers, 80 (4), 504-530.

Ó Tuathail, G 1992, 'The Bush Administration and the 'End' of the Cold War: A Critical Geopolitics of US Foreign Policy in 1989', Geoforum, 23 (4), 437-452.

Ó Tuathail, G \& Agnew, J 1998, 'Geopolitics and Discourse: Practical Geopolitical Reasoning in American Foreign Policy' in Ó Tuathail, G Dalby \& S Routledge (eds) The Geopolitics Reader, Routledge, New York, 78-91.

Saarinen, T 2005, 'Student Views of the World' in R Downs \&D Stea (eds) Image and Environment: Cognitive Mapping and Spatial Behavior, Transaction Publishers, New Brunswick, New Jersey, 148-161.

Saarinen, Thomas (1987), Centering of Mental Maps of the World: Discussion Paper. Tuscon, Arizona: University of Arizona.

Scheffler, T 2003, 'Fertile Crescent', 'Orient', 'Middle East': The Changing Mental Maps of Southwest Asia', European Review of History, 10 (2), 253-272.

Sloan, G 1988, Geopolitics in the United States Strategic Policy, 1890-1987, St. Martin's Press, New York.

Snyder, R, Bruck, H \& Sapin, B (eds) 2002, Foreign Policy Decision-Making (Revisited), Palgrave-Macmillan, New York. 
Sprout, H \& Sprout, M 1957, 'Environmental Factors in the Study of International Politics', Journal of Conflict Resolution, 1 (4), 309-328.

Sprout, H \& Sprout, M 1960, 'Geography and International Politics in an Era of Revolutionary Change', Journal of Conflict Resolution, 4 (1), 145-161.

Sprout, H \& Sprout, M 1965, The Ecological Perspective on Human Affairs: With Special Reference to International Politics, Princeton University Press, Princeton, New Jersey

Thomas, M (ed.) (forthcoming), The French Colonial Mind: Mental Maps of Empire and Colonial Encounters, University of Nebraska Press. Lincoln, NE.

Tolman, E 1948, 'Cognitive Maps in Rats and Men', The Psychological Review, 55 (4), 189-208.
Trowbridge, C 1913, 'On Fundamental Methods of Orientation and 'Imaginary Maps", Science, 38 (990), 888896.

Tversky, B 2003, 'Structures of Mental Spaces: How People Think About Space', Environment and Behavior, 35 (1), 6680.

Unwin, T 1995, El Lugar de la Geografía, Cátedra, Madrid. Walker, M 200o, 'Variable Geography: America's mental maps of Greater Europe', International Affairs, 76 (3), 459474 .

Wolpert, J 1964, 'The Decision Process in Spatial Context', Annals of the Association of American Geographers, 54 (4), 537-558. 